DOI: https://doi.org/10.15407/techned2020.05.049

\title{
ADJUSTMENT OF THE MATLAB SURGE ARRESTER MODEL PARAMETERS
}

$\quad$ Journal
Publisher
ISSN
Issue
Pages

Tekhnichna elektrodynamika

Institute of Electrodynamics National Academy of Science of Ukraine 1607-7970 (print), 2218-1903 (online)

No 5, 2020 (September/October)

Pages

$49-53$

\section{Author}

\section{O. Shpolianskyi*}

Institute of Electrodynamics National Academy of Sciences of Ukraine,

Peremohy, 56, Kyiv, 03057, Ukraine,

e-mail: shpolyanskyy@ied.org.ua

* ORCID ID : https://orcid.org/0000-0002-0167-2234

\section{Abstract}

This article proposes a method for the parameters adjustment of the Matlab Simscape library Surge Arrester block. It is based on building of nonlinear V-I characteristic by approximation of residual voltage and impulse current obtained from manufacturer catalogs. Given parameters of the exponential function are checked by transient simulations under impact of standard current impulses on surge arresters. References 14, figure 1, tables 3.

Key words: zinc oxide surge arresters, parameters of mathematical model, residual voltage, impulse of current.

Received: 07.02.2020

Accepted: 30.06 .2020

Published: 25.08.2020 
The article was prepared on the basis of research within the scientific project No.: III-32-19 "Development of methods and models for the analysis of electromagnetic transient processes in order to prevent overvoltage". Program code of classification of expenses «6541030».

\section{References}

1. Kuznetsov V.G., Tugai Yu.I., Shpolianskyi O.G. Research of internal overvoltages in main electric networks of ultrahigh voltage and development of measures for their prevention and limitation. Pratsi Instytutu elektrodynamiky NAN Ukrainy. 2013. Is. 35. Pp. 117-123. (Ukr) 2. Shpolianskyi O.G. Reduction of overvoltages and aperiodic currents when connecting $750 \mathrm{kV}$ transmission lines with the help of controlled switching devices. International Ukraine - Poland Seminar Power quality in distribution networks with distributed generation , Kyiv, Ukraine, July 4-5, 2019. Pp. 197-202.

3. Haddad A., Warne D. Advances in high voltage engineering. London: Institution of Engineering and Technology. IEE Power Energy Series 40. 2004. 647 p. DOI: https://doi.org/1 0.1049/PBPO040E

4. MathWorks.URL: https://www.mathworks.com/help/physmod/sps/powersys/ref/surgearrester. html?searchHighlight=surge\&s tid=doc srchtitle (accessed 31.01.2020) 5. Lira G. R. S., Fernandes D., Costa E. G. Parameter Identification Technique for a Dynamic Metal-oxide Surge Arrester Model. International Conference on Power Systems Transients, Kyoto, Japan, 2009. URL:

https://www.ipstconf.org/papers/Proc_IPST2009/09IPST023.pdf (accessed 31.01.2020)

6. Zadeh M., Abnik H., Shayegani Akmal A. A. The modeling of metal-oxide surge arrester applied to improve surge protection. 2nd International Conference on Power Electronics and Intelligent Transportation System China, 2009. Vol. 1. Pp. 239-243.

(PEITS), Shenzhen,

DOI:

https://doi.org/10.1109/PEITS.2009.5407027

7. Nafar M., Solookinejad G., Jabbari M. Comparison of IEEE and Pinceti Models of Surge Arresters. Research Journal of Engineering Sciences. 2014. Vol. 3(5). Pp. 32-34.

8. Agrawal K. C. Electrical Power Engineering: Reference \& Applications. Handbook. CRC Press, 2007. $1125 \mathrm{p}$.

9. Surge arresters. Part 4: Metal-oxide surge arresters without gaps for AC systems. IEC Standard 60099-4, 2014.

10. Volker Hinrichsen. Metal-Oxide Surge Arresters in High-Voltage Power Systems.

Fundamentals. Siemens AG, Erlangen, Germany, 2012. 128 p.

11. Metal-oxide surge arresters in medium-voltage systems. ABB Switzerland Ltd, Wettingen,

Switzerland. 2018. $60 \mathrm{p}$. 
12. Electromagnetic compatibility (EMC). Part 4-5: Testing and measurement techniques Surge immunity test. IEC Standard 61000-4-5 Edition 3.0, 2014.

13. High voltage surge arresters. Buyer's guide. ABB AB, Ludvika, Sweden. 2019. 132 p.

14. High-voltage surge arresters. Product guide. Siemens AG, Erlangen, Germany. 2014. 112 p.

$\underline{\text { PDF }}$

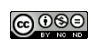

This work is licensed under a Creative Commons Attribution-NonCommercial-NoDerivatives $\underline{4.0 \text { International License }}$ 